\title{
An Evaluation of the Factors Influencing Investors' Perception in Bangladesh Stock Market
}

\author{
Jannatunnesa $^{1}$ \\ ${ }^{1}$ Department of Business Administration, Faculty of Business and Economics, East West University, Dhaka, \\ Bangladesh
}

Correspondence: Jannatunnesa, Senior Lecturer, Department of Business Administration, Faculty of Business and Economics, East West University, Dhaka, Bangladesh. E-mail: moniducbl68@yahoo.com

Received: February 15, 2017

Accepted: March 22, 2017 Online Published: April 27, 2017

doi:10.5539/ijbm.v12n5p89

URL: https://doi.org/10.5539/ijbm.v12n5p89

\begin{abstract}
Behavioral finance deals with the influence of psychology on the behavior of financial practitioners and its subsequent impact on stock markets. Unlike the developed part of the globe, very limited research attempts have been undergone so far in the field of investors' behavior in the growing stock markets. However, the decisions of investors in an emergent market are generally influenced by behavioral finance rather than conventional finance. Thus, this study aims at analyzing the general behavior of individual investors in Bangladesh in terms of the factors affecting their stock market perception. The study is mainly based on primary data, collected particularly in the context of Bangladesh. In exposing the factors affecting the perception of individual investors, a number of statistical techniques under univartate, bivariate and multivariate analysis have been applied using SPSS. According to the study, Accounting Information is the most important factor influencing investors' decision, whereas Company Specific Attributes or Reputation is the least important factor. The findings of the study may offer important implications to the concerned parties, especially to the actual and potential investors, corporations' management, investment managers, regulatory body, etc.
\end{abstract}

Keywords: general investment behavior, individual investors, influencing factors

\section{Introduction}

"People in standard finance are rational. People in behavioral finance are normal" Statman (2008) Investors' absurdity is an unpredictable veracity that has been the center of attention of researchers all over the world. As stated by Sewell (2010), behavioral finance is concerned with the impact of psychology on the perception of investors, which has ultimate impact on stock markets. Rational expectations theory assumes investors to behave rationally and in their self-interest, with intent to earn maximum returns at a given risk level. Nonetheless, the reality is that investors make imperfect investment decisions and tend to make the same mistakes repeatedly, such as, buying and selling frequently; going after the herd; having preference for the familiar; selling the winning positions and holding onto losing positions; short-term thinking, and being overconfident. Advocates of behavioral finance focus on the social, cognitive, and emotional factors that motivate investors to behave in a manner different from the rational behavior suggested by standard economic theory (Aregbeyen \& Mbadiugha, 2011; Barber \& Odean, 1999; Elan, 2010; Kahneman \& Tversky, 1979; Mohacsy \& Lefer, 2007; Shefrin \& Statman, 1985). Jagongo and Mutswenje (2014) assumed both information structure as well as the factors in the market to have systematic influence on individual's investment decisions and overall market results. These factors tend to spot light on how investors differ in interpreting and acting on information while making their investment decisions.

In the recent years, numerous research works have been attempted in the area of investors' perception about equity market and their stock investment decisions. These studies mostly focused on the financial markets of individual countries as well as particular regions of the globe. Nevertheless, inadequate research attempts have been endured so far in the field of investors' behavior focusing on the stock market of developing countries.

This study aimed at analyzing the factors affecting the investment decisions of individual investors in the stock market of Bangladesh. In view of that, the venture of this study was to find out the features influencing investment decision of individual investors that can fundamentally account for a number of scrutinized variables. Moreover, attempts were made to categorize the variables precisely into a few principal factors and recognize the 
relative significance of each of the factors. Further, the study also investigated the influence of investors' general investment behavior on each of the principle factors (variables). By combining all these aspects of investors' behavior, this research crafts exceptional appeal to the existing literature of behavioral finance in developing countries, especially in the context of Bangladesh.

The research was based mainly on primary data gathered and processed through questionnaire survey. It covers an exploratory study involving purposive sampling. A number of statistical tools such as frequencies, mean scores, standard deviations, percentages, and one way Analysis of Variance (ANOVA) were used in the data analysis process employing the statistical software SPSS. Initially the study explicitly researched on the general investment behavior of retail investors using frequency distribution. In addition, a number of variables have been examined using a five point Likert scale to check their influence on the investment decision of individual investors and thus, ranked according to investors' preference. The variables are then categorized into five leading factors named company specific attributes, accounting information, reliability of information, influence of others (peer) and investors' action in specific situations. In order to analyze the comparative importance of each of the factors, a ranking table of the key factors has been derived on the basis of mean scores of the factors as well as individual items included in each factor category. Finally, using one way Analysis of Variance (ANOVA), the relative significance of each of these principal factors have been examined in relation to the general investment characteristics of investors such as their trading experiences with Dhaka Stock Exchange (DSE), investment frequencies, sources of fund, investment thoughts, and expected gain from investments.

\section{Problem Statement}

The stock market of Bangladesh, specifically DSE has been observing instability since its commencement (Hossain and Uddin, 2011). The indices attained the peak in its history in November, 1996 and ultimately the market collapsed. The consequential lack of confidence of investors on the stock market directed regulators to attempt for restructuring the market through automated operation in 1998. Further, stock market collapse of 2010-11 has been a national, political and social concern of the country. The crash swabbed out a huge amount of money from the market where fresh, unaware individual investors were the major losers. According to the research recently carried out by Centre for Policy Dialogue (CPD) (2011 cited in Faruqui and Rahman, 2013, p.141), most of these fresh investors didn't have enough knowledge about the stock market. Still, they invested more or less all of their savings in the market. Even after a number of years since the crash had transpired; the market is still struggling to salvage its losses. In fact, such malfunctioning of Bangladesh stock market time and again affects mostly individual investors.

One of the most important reasons for high instability in Bangladesh stock market may be irrational behavior of retail investors who are the major players in capital market (Hossain and Nasrin, 2012). In this scenario, recognizing the decision making criteria of investors have become crucial. However, the decisions of retail investors in an emerging market are typically affected by behavioral finance rather than conventional finance. Therefore, it is important to ascertain the general behavior of investors and also the factors that influence investor's sentiment in trading equity shares. If financial planners have detailed understanding of these behavioral issues related to investors' insight in the investment decisions, they can attempt to control these influencing factors to such an extent that brings stability in the market. Thus, this study proceeded with the following research questions:

1) How does the general investment behavior of retail investors enlighten their stock market investment situations?

2) What are the factors affecting the investment decisions of individual investors and how does each of these factors persuade such decisions?

3) Are general investment aspects of retail investors related to the factors influencing their investment decisions? If yes, how?

\section{Rationale for the Study}

The endeavor of this study was to understand the general behavior of investors in the capital market of Bangladesh, especially the stock market, and examine the factors which affect decisions of investors. Very few studies have been conducted so far concerning individual investors' behavior in Bangladesh. Thus, the study is expected to enrich the existing behavioral finance literature by presenting evidence on the behavioral issues of stock market investors. Investors with similar characteristics in the country and elsewhere in the world can follow the findings and recommendations offered in this study in planning their investments. Besides, corporations can update their future policies and strategies in accordance with their knowledge of the factors 
influencing their investors' decisions. Moreover, findings of this research will also be useful to stock market dealers and brokers in understanding investors' inclination and thus, enabling them in improving their services. Further, the research can also have important practical implications for government regulators in the capital market of Bangladesh.

\section{Literature Review}

Numerous research have been done so far in the area of individual investors' behavior in the capital market (Baker \& Wurgler, 2007; Baker, Wurgler, \& Yuan, 2012; Barber \& Odean, 2000; Barber \& Odean, 2008; Conrad, Kapadia \& Xing, 2014; Grinblatt \& Keloharju, 2000; Jariwala, 2015; Odean, 1998 [a], [b]; Ovat, O.O., 2012; Stambaugh, Yu, \& Yuan, 2012; Viswanadham et. al., 2014; Yu \& Yuan, 2011).

Empirical studies focused on the behavioral aspects of investors in different countries of the world like Finland (Grinblatt \& Keloharju, 2000); Greece (Merikas et al., 2004), Nigeria (Aregbeyen \& Mbadiugha, 2011; Ovat, O.O., 2011); Nairobi (Jagongo \& Mutswenje, 2014); Tanzania (Viswanadham, et. al., 2014); Ghana (Bennet et. al., 2011); United States (Kumar, 2009; Elan, 2010; Shiller, 2000). Research has also been conducted focusing on the investors of a particular region of the world (Mobarek, Mollah, \& Keasey, 2014; Kamstra, Kramer, \& Levi, 2003). Besides, a number of studies have been conducted so far on investors in the stock market of Asian region specifically; China (Shumway \& Wu, 2006); India (Prosad, 2014; Rakesh, 2014; Bhatt, 2013; Joshi, Khusboo \& Desai, 2011; Jains and Dashora, 2012; Mohanta \& Debasish, 2011); Japan (Kamesaka, Nofsinger \& Kawakita, 2003); Malaysia (Chong \& Lai, 2011); Pakistan (Iqbal \& Usmani, 2009; Lodhi, 2014); UAE (Al-Tamimi, 2006).

Over the past decades numerous studies spotted light on the factors having influence on individual investors' investment behavior. Al-Tamimi (2006) attempted to examine investors' behavior in UAE financial markets by categorizing 34 variables under five principal factors. His study concluded that expected earnings, desire to get rich quickly, marketability of stock, preceding stock performance, government holdings, and structured financial market are the most influential individual factors according to investors.

Joshi, Khusboo and Desai (2011) found that investors are typically influenced by factors like a company's financial performance, performance trend of the stock in the long term, attitude towards stock market, expectations from the company in terms of cash dividend, bonus share, etc, company repute, movement of stock market, and affordability of share price.

The research of Mills, Steven and Warren (1994) launched that financial factors have considerable influence on investment decisions, and a firm's balance sheet and monetary policy influence the investment decision of the equity market investors. According to Sehgal and Tripathi (2007), company specific factors, such as firm size, book to market equity, price earnings ratio, leverage, etc. have considerable influence on stock prices. Merikas et al. (2004) revealed that investors make their investment decision based on the price indices, latest stock price movement firms, and existing economic pointers. In another study, Merikas et al. (2004) investigated 150 individual investors in the stock market of Greece, and concluded that investors mostly emphasize expected earnings, financial statement conditions and status of particular firms in the industry in taking their investment decisions. Chong and Lai (2011) examined Malaysian customers and found that they place much importance on the past performance of a firm's stock, latest price movements, and firm's status in the pertinent industry. As stated by Bennet, et al. (2011), return on equity (ROE), management quality, return on investment (ROI) and price to earnings (P/E) ratio influence the decision makers. The research of Aregbeyen and Mbadiugha (2011) revealed that investment decisions of Nigerian investors are persuaded by economic, social, cultural and psychological aspects.

A few studies attempted by researchers, especially on Bangladeshi investors, recognize several factors (variables) that influence their investment decisions such as analysis of investment, simplicity of transaction, information management, risk management, advice of brokers, friends and family, affordability of price, availability of borrowed fund and prior performance (Rashid \& Nishat, 2009; Akhter \& Ahmed, 2013; Hossain \& Nasrin, 2012; Faruqui \& Rahman, 2013; Farzana, Rahman, \& Mazumder, 2012). The study of Jannatunnesa (2015) spotted light on demographic and general investment characteristics of retail investors, particularly investing in Dhaka Stock Exchange (DSE). However, most of the studies in Bangladesh involve very small sample size compared to the overall market. Besides, very inadequate focus has been given so far on detailed analysis of the factors with respect to the demographic features as well as general behavior of retail investors.

Hence, this study intends to contribute to the financial literature of Bangladesh by evaluating the factors that have influence on the investment decision of individual investors, and the relative importance of each of the factors with respect to their general investment features. The present research will be an endeavor to bestow in 
this area through an investigation of some relevant variables and their impact on retail investors' investment decisions.

\section{Methodology}

The study is an exploratory one comprising of both primary and secondary data, especially in the milieu of Bangladesh. Primary data has been assembled through a survey conducted on 150 retail investors trading in different brokerage houses in Dhaka Stock Exchange and Chittagong Stock Exchange. Besides, secondary data has been collected from pertinent newspapers, magazines, research articles, websites, etc.

While conducting the survey, questionnaire has been distributed using online platform and offline platform through individual brokers. Data has been collected from the respondents following purposive sampling technique. The survey questionnaire has been organized in three sections. The first part of the questionnaire includes demographic information of the respondents characterized by their gender, age, level of education, occupation, income, etc. The second section of the questionnaire consists of information related to general stock market investment behavior of respondents such as their trading experiences in stock market, expected gain, sources of fund, types of trading account, etc. The third section of the questionnaire asked respondents to rate the relative importance of a number of variables (items), which are taken into account by them in making their stock market investment decisions. The first and second sections consist of multiple choice questions. However, the variables, in the third section, have been measured on a five point Likert-type scale of performance ranging from 1 (most preferred) to 5 (least preferred).

The survey data were analyzed in SPSS using a number of statistical tools. Basic descriptive statistics such as frequency distribution was used to quantify the general investment features of the respondents. In this regard, multiple answers of the survey respondents were addressed separately as multiple response variables in SPSS and analyzed in view of that. Besides, a number of variables have been selected and examined in terms of their comparative importance to investors based on their descriptive statistics. The variables were then categorized under a number of prime factors, and the relative importance of each of these main factors is shown using a ranking table. Such ranking has been developed on the basis of the mean scores of factors as well as the mean score of individual variables included in those factors. Finally, the study employed one way ANOVA test to observe the influence of each of the key factors on the investment decisions of retail investors in terms of their general investment behavior.

\section{Empirical Analysis}

The study sought to explore the behavior of investors in terms of the factors affecting their investment decisions in the stock market of Bangladesh. A number of statistical tools, such as frequency distribution, ranking table based on mean values, and ANOVA (one way) have been employed using SPSS to evaluate the primary data obtained from the survey.

\subsection{Analysis of General Investment Behavior of Retail Investors}

Table 1 presents the frequency distribution of general investment characteristics of retail investors in Bangladeshi stock market.

Stock market of Bangladesh is mostly compacted by experienced investors. Among the investors, $37.3 \%$ have investment experience of 5-10 years and 27.3\% are investing for more than 10 years. Besides, $33 \%$ of the investors have been involved in stock market investment for 1-5 years. However, only $2 \%$ investors have less than 1 year of experience.

Investors mostly perform very frequent (0-3 months) investment in stock market. Additionally, $30.8 \%$ of them invest every 3-12 months, $20 \%$ of the investors invest within 1-3 years and very few (only 5.3\%) invest after every 3 years.

Greater part $(72.7 \%)$ of the investors prefer to buy securities in bullish market, whereas, only $27.3 \%$ would like to buy shares in an underpriced market. None of them want to buy shares in a bearish or over priced market.

Before making an investment, emphasize is given mostly (44.7\%) on investors' security of investment in terms of their risk-return trade off. Secondly, $41.3 \%$ investors focus on potential gain. Yet, $13.3 \%$ think about both potential gain and loss.

Investors' own financing has preponderance as the source of fund for stock market investment. 56\% investors invest their own fund in stocks and $42 \%$ use both their own and borrowed fund. 
Most of the investors (64\%) invest between BDT 0.2-2 million. 15.3\% investors comprise investment size of BDT 2-10 million and $14.7 \%$ invest more than BDT 110 million However, only $6 \%$ investors invest less than BDT 0.2 million.

$38 \%$ investors have expectation for an average annual return of 20\%-30\% from their investment. Besides, $30 \%$ investors expect $30 \%-50 \%$ gain and $14.7 \%$ expect more than $50 \%$ gain per annum. On the other hand, $17.3 \%$ investors have return target of $10 \%-20 \%$.

$78 \%$ investors stay away from stock market investment in different situations. However, $22 \%$ of the investors have uninterrupted presence in the market.

Table 1. Frequency distribution of general investment behavior of the respondents

\begin{tabular}{|c|c|c|c|}
\hline Variable & Category & Frequency & Percent \\
\hline \multirow[t]{5}{*}{ Investment experience } & Less than 1 year & 3 & 2 \\
\hline & 1-3 years & 26 & 17.3 \\
\hline & 3-5 years & 24 & 16 \\
\hline & $5-10$ years & 56 & 37.3 \\
\hline & Above 10 years & 41 & 27.3 \\
\hline \multirow[t]{4}{*}{ Investment frequency } & Every 0-3 months & 46 & 30.7 \\
\hline & Every 3-12 months & 66 & 44 \\
\hline & Every $12-36$ months & 30 & 20 \\
\hline & Every 36 months or more & 8 & 5.3 \\
\hline \multirow[t]{2}{*}{ Preferred market condition } & Buy in bullish market (rising price) & 109 & 72.7 \\
\hline & Buy in underpriced market & 41 & 27.3 \\
\hline \multirow[t]{4}{*}{ Investment focus (thought) } & Mostly about the potential gain & 62 & 41.3 \\
\hline & Mostly about potential loss & 1 & 0.7 \\
\hline & Both potential gain and loss & 20 & 13.3 \\
\hline & Security of investment (i.e. risk v/s return) & 67 & 44.7 \\
\hline \multirow[t]{3}{*}{ Form (Source) of financing } & Own fund & 84 & 56 \\
\hline & Borrowed fund & 3 & 2 \\
\hline & Own and borrowed fund & 63 & 42 \\
\hline \multirow[t]{5}{*}{ Investment size $^{1}$} & Below BDT 0.2 million & 9 & 6 \\
\hline & BDT 0.2-BDT 0.5 million & 51 & 34 \\
\hline & BDT 0.5-BDT 2.0 million & 45 & 30 \\
\hline & BDT 2.0-BDT 10 million & 23 & 15.3 \\
\hline & Above BDT 10 million & 22 & 14.7 \\
\hline \multirow[t]{4}{*}{ Expected gain } & $10 \%-20 \%$ & 26 & 17.3 \\
\hline & $20 \%-30 \%$ & 57 & 38 \\
\hline & $30 \%-50 \%$ & 45 & 30 \\
\hline & Above $50 \%$ & 22 & 14.7 \\
\hline \multirow[t]{2}{*}{ Staying away from investment } & Yes & 117 & 78 \\
\hline & No & 33 & 22 \\
\hline
\end{tabular}

\subsection{Analysis of General Investment Behavior of Retail Investors (Multiple Responses)}

While carrying out the survey for assembling data, multiple responses were received from investors to a number of questions. Such multiple responses were defined and scrutinized statistically as multiple response variables for analysis in SPSS. Table 2 depicts frequency distribution based on the investors' multiple responses representing 
their general investment behavior.

- Investment Purpose: Investors have a number of purposes for investing in stock market. 56.7\% of them invest for multiple purposes. Specifically, most (32.3\%) of the investors invest for their personal interest in stock market. $23.8 \%$ want to meet their family needs in future, $27.2 \%$ go to stock market seeing others making profit and $11 \%$ want to earn abnormal return in the short run. It is interesting that very few people (5.5\%) go there to earn their day to day expenditure.

- Reasons for Staying Away From Investment: Political instability and abnormal market fluctuation play vital role keeping $58.1 \%$ and $56.4 \%$ investors (respectively) away from the market. More to the point, $34.7 \%$ and $33.7 \%$ investors emphasize particularly on these two reasons. In addition, $17.9 \%$ and $13.8 \%$ investors stay away from market for unavailability of fund and regulatory policy reforms respectively.

- Responses to Share Price Decrease: Investors address the decrease in stock prices in various manners. When the price of stocks decrease immediately after they buy those, $38 \%$ investors ignore temporary changes and hold on the stock for long term growth. Conversely, $28.4 \%$ investors discuss this situation with their fellow traders before taking decision. However, $17.8 \%$ investors get rid of the worries by selling those stocks, and try something else. Still $15.9 \%$ attempt to reduce the average cost by adding more of the shares to their portfolios.

- Responses to Share Price Increase: In response to a jump in the price of shares after purchase, about 35\% investors hold on the stocks expecting more gains, and $30.4 \%$ lock in the gains by selling the stocks. In contrast, $27.1 \%$ investors discuss this situation with fellow traders and take decision accordingly.

Table 2. Frequency distribution (multiple responses) of general investment behavior of respondents

\begin{tabular}{|c|c|c|c|c|}
\hline \multirow[b]{2}{*}{ Variable } & \multirow[b]{2}{*}{ Category } & \multicolumn{2}{|c|}{ Responses } & \multirow{2}{*}{$\begin{array}{l}\% \text { of } \\
\text { Cases }\end{array}$} \\
\hline & & Frequency & $\%$ & \\
\hline \multirow[t]{7}{*}{ Investment Purposes } & Meet family needs in future & 56 & 23.8 & 37.3 \\
\hline & Personal interest about stock market & 76 & 32.3 & 50.7 \\
\hline & Seeing others make profit & 64 & 27.2 & 42.7 \\
\hline & Earn abnormal gain in short run & 26 & 11.1 & 17.3 \\
\hline & Earn day-to-day family expenditures & 13 & 5.5 & 8.7 \\
\hline & Total & 235 & 100 & 156.7 \\
\hline & Political instability & 68 & 34.7 & 58.1 \\
\hline Reasons for Staying & Abnormal fluctuation in the market & 66 & 33.7 & 56.4 \\
\hline \multirow[t]{4}{*}{ Away from Investment } & Unavailability of fund & 35 & 17.9 & 29.9 \\
\hline & Policy reform by SEC or DSE/CSE & 27 & 13.8 & 23.1 \\
\hline & Total & 196 & 100 & 167.5 \\
\hline & Ignore temporary changes and hold on stocks for long term & 79 & 38 & 52.7 \\
\hline Responses to Price & Buy more to reduce the average cost & 33 & 15.9 & 22 \\
\hline \multirow[t]{4}{*}{ Decreases } & Sell it to avoid further worries and try something else & 37 & 17.8 & 24.7 \\
\hline & Do what the fellow traders are doing & 59 & 28.4 & 39.3 \\
\hline & Total & 208 & 100 & 138.7 \\
\hline & Hold on the stock and hope for more gains & 72 & 34.8 & 48 \\
\hline Responses to Price & Buy more as the price could go higher & 16 & 7.7 & 10.7 \\
\hline \multirow[t]{3}{*}{ Jumps } & Sell it and lock in the gains & 63 & 30.4 & 42 \\
\hline & Do what the fellow traders are doing. & 56 & 27.1 & 37.3 \\
\hline & Total & 207 & 100 & 138 \\
\hline
\end{tabular}

\subsection{Analysis of Factor Influencing Investment Behavior of Individual Investors}

A total of 24 variables have been examined which are assumed to direct the investment decision of individual 
investors in stock market. The variables include (1) company size, (2) age of the company, (3) company reputation, (4) status of the firm in industry, (5) Earnings Per Share (EPS), (6) Return on Equity (ROE), (7) dividend paid by the firm, (8) expected non-cash dividends, (9) growth of the firm, (10) firm's Debt to Equity ratio, (11) information obtained from internet, (12) fluctuations in stock indices, (13) information from newspapers, articles, etc., (14) brokers' analysis, (15) market movement (rumor), (16) family members, (17) friends, (18) brokers' influence, (19) financial Consultant, (20) analysts' forecasts in news media, (21) buy/sell shares with market price changes (22) willingness to purchase different types of stocks to reduce risk, (23) increase in investment with availability of borrowed fund and (24) willingness to take high risk for high returns. These variables are selected based on the relevant literature (Al-Tamimi, 2006; Kaleem, Wajid, and Hussain, 2009; Merikas et al., 2004; Nagy and Obenberger, 1994), personal know-how, and interviews with investors. Respondents were asked to indicate the degree of influence of each of the items on a five point Likert scale ranging from 'most preferred' to 'least preferred' ranked as $1=$ most preferred, $2=$ preferred, $3=$ neutral, $4=$ less preferred and $5=$ Least preferred.

The items are then categorized into five leading factors such as company specific attributes, accounting information, reliability of information, influence of others (peer) and investors' action in specific situations. Here, Company Specific Attributes include size, age, reputation, and status of the firm in the industry. Accounting Information consists of variables such as EPS, ROE, dividend paid, expected non-cash dividends, firm growth and firm's Debt/Equity ratio. The factor Reliability of Information comprises of information obtained from internet, stock indices fluctuations, information from newspapers, articles, etc., brokers' analysis, and market movement. Influence of Others (peer) contains family members, friends, brokers' influence, financial consultants, and analysts' forecasts in news media. Investors' Action in Specific Situations is another factor which includes items such as trading of shares with market price changes, willingness to purchase different types of stocks to reduce risk, increase in investment with availability of borrowed fund, and compliance with high risk for high returns.

\subsubsection{Ranking of Variables and Factors Influencing Stock Investment Decisions}

Ranking of the mean values of importance has been used to find out which of the examined variables is given the highest importance by the respondents. For this purpose, the mean level of importance of each item on the Likert scale has been calculated.

Table 3. Descriptive statistics of variables influencing investors' decisions

\begin{tabular}{|c|c|c|c|c|c|c|}
\hline $\begin{array}{l}\text { Serial } \\
\text { No. }\end{array}$ & Variable Name & $\begin{array}{c}\text { Frequency } \\
\text { (Mode) }\end{array}$ & $\begin{array}{l}\operatorname{Max} \\
(\%)\end{array}$ & $\begin{array}{l}\text { Variable } \\
\text { Mode }\end{array}$ & $\begin{array}{c}\text { Variable } \\
\text { Mean }\end{array}$ & $\begin{array}{c}\text { Variable } \\
\text { SD }\end{array}$ \\
\hline 1 & Firm's Debt to Equity ratio & 91 & 60.7 & 3 & 3.62 & .988 \\
\hline 2 & Information obtained from internet & 65 & 43.3 & 4 & 3.57 & .814 \\
\hline 3 & Analysts forecasts in News media & 42 & 28.0 & 3 & 3.41 & 1.112 \\
\hline 4 & Return on Equity & 85 & 56.7 & 3 & 3.35 & .898 \\
\hline 5 & Financial Consultant & 99 & 66.0 & 3 & 2.97 & .789 \\
\hline 6 & Growth of the firm & 40 & 26.7 & 1 & 2.79 & 1.398 \\
\hline 7 & Expected non-cash dividends & 72 & 48.0 & 3 & 2.74 & .772 \\
\hline 8 & Newspapers, articles, etc. & 63 & 42.0 & 2 & 2.66 & 1.128 \\
\hline 9 & Willing to take high risk for high returns & 85 & 56.7 & 3 & 2.65 & .770 \\
\hline 10 & Dividend paid by the firm & 94 & 62.7 & 3 & 2.59 & .779 \\
\hline 11 & Friends & 70 & 46.7 & 3 & 2.44 & .839 \\
\hline 12 & Family members & 69 & 46.0 & 3 & 2.32 & .951 \\
\hline 13 & Buy different types of stocks to reduce risk & 76 & 50.7 & 2 & 2.18 & .927 \\
\hline 14 & Buy/sell shares with market price changes & 60 & 40.0 & 1 & 2.11 & 1.232 \\
\hline 15 & Brokers' Influence & 83 & 55.3 & 2 & 2.09 & .777 \\
\hline 16 & Fluctuations in the stock index & 61 & 40.7 & 1 & 2.00 & .962 \\
\hline 17 & Market movement (rumor) & 98 & 65.3 & 1 & 1.67 & 1.120 \\
\hline 18 & Earnings per share & 84 & 56.0 & 2 & 1.61 & .577 \\
\hline 19 & Brokers' Analysis & 91 & 60.7 & 1 & 1.56 & .781 \\
\hline 20 & Status of the firm in industry & 108 & 72.0 & 1 & 1.41 & .724 \\
\hline 21 & Age of the company & 113 & 75.3 & 1 & 1.29 & .550 \\
\hline 22 & Size of the company & 122 & 81.3 & 1 & 1.27 & .620 \\
\hline
\end{tabular}




\begin{tabular}{rllllll}
\hline 23 & $\begin{array}{l}\text { Increase investment when borrowed fund is easily } \\
\text { available }\end{array}$ & 125 & 83.3 & 1 & 1.23 & .545 \\
24 & Reputation of the company & 127 & 84.7 & 1 & 1.17 & .424 \\
\hline
\end{tabular}

First, the descriptive statistics are calculated and an overall ranking is conducted for all the items based on their mean values. As presented in Table 3, all the 24 variables somehow affect the investment decision of Bangladeshi investors. However, firm's Debt/Equity ratio, information obtained from internet, and analysts' forecasts in news media can be recognized as the three most important variables manipulating investment decision of individual investors. On the other hand, company reputation, increase in investment with easily available borrowed fund, and company size are the factors that investors consider least important in making their investment decisions.

Next, the mean values of items classified into each factor group are consolidated to get a single value for each category as shown in Table 4.

Table 4. Descriptive Statistics of the Factor Categories Comprising of the Variables Influencing Investors' Decisions

\begin{tabular}{|c|c|c|c|c|c|c|}
\hline No. & Items & Factor Categories & Mean & Median & Mode & SD \\
\hline 1 & Size of the company & Company Specific Attributes & 1.28 & 1.25 & 1 & 0.2743 \\
\hline 2 & Age of the company & & & & & \\
\hline 3 & Reputation of the company & & & & & \\
\hline 4 & Status of the firm in industry & & & & & \\
\hline 5 & Earnings per share & Accounting Information & 2.78 & 2.67 & 2.5 & 0.5184 \\
\hline 6 & Return on Equity & & & & & \\
\hline 7 & Dividend paid by the firm & & & & & \\
\hline 8 & Expected non-cash dividends & & & & & \\
\hline 9 & Growth of the firm & & & & & \\
\hline 10 & Firm's Debt to Equity ratio & & & & & \\
\hline 11 & Information obtained from internet & Reliability of Information & 2.29 & 2.2 & 2 & 0.4175 \\
\hline 12 & Fluctuations in the stock index & & & & & \\
\hline 13 & Newspapers, articles, etc. & & & & & \\
\hline 14 & Brokers & & & & & \\
\hline 15 & Market movement (rumor) & & & & & \\
\hline 16 & Family members & Influence of Others (Peer) & 2.65 & 2.6 & 2.6 & 0.3538 \\
\hline 17 & Friends & & & & & \\
\hline 18 & Brokers & & & & & \\
\hline 19 & Financial Consultant & & & & & \\
\hline 20 & Analysts forecasts in News media & & & & & \\
\hline 21 & Buy/sell shares when price changes in the market & $\begin{array}{l}\text { Investors Action in Specific } \\
\text { Situations }\end{array}$ & 2.04 & 2 & 2 & 0.4336 \\
\hline 22 & $\begin{array}{l}\text { Willing to buy different types of stocks to reduce } \\
\text { risk }\end{array}$ & & & & & \\
\hline 23 & $\begin{array}{l}\text { Increase investment when borrowed fund is easily } \\
\text { available }\end{array}$ & & & & & \\
\hline 24 & Willing to take high risk for high returns & & & & & \\
\hline
\end{tabular}

Then ranking is done by leveling rank 1 to the factor with the highest mean and so on. Summary of the descriptive statistics of the prime factors and their ranking is presented in Table 5. According to this study, among the principal factors influencing retail investors, the most important is Accounting Information with a mean value of 2.78 followed by Influence of peer (mean=2.65), Reliability of Information (mean=2.29), Investors' Action in Specific Situations (mean=2.04), and Company Specific Attributes or Reputation $($ mean $=1.28)$. 
Table 5. Summary of Descriptive Statistics of the Factors and Ranking

\begin{tabular}{lccccc}
\hline Factor Categories & Mean & Median & Mode & SD & Rank \\
\hline Accounting Information & 2.78 & 2.67 & 2.50 & 0.5184 & 1 \\
Influence of Others (Peer) & 2.65 & 2.60 & 2.60 & 0.3538 & 2 \\
Reliability of Information & 2.29 & 2.20 & 2.00 & 0.4175 & 3 \\
Investors' Action in Specific Situations & 2.04 & 2.00 & 2.00 & 0.4336 & 4 \\
Company Specific Attributes (Reputation) & 1.28 & 1.25 & 1.00 & 0.2743 & 5 \\
\hline
\end{tabular}

\subsection{One Way Analysis of Variance (ANOVA)}

Finally one way ANOVA test has been performed to verify whether factors influencing investment decisions of retail investors have significant deviation among investors having different levels of stock trading experience, investment frequency, sources of fund, investment focus, and gain expectation from their investments. To enhance the understanding of the factors influencing the equity selection decision, the following null hypotheses have been tested for the principal factors:

1) There is no significant difference between investors' experience and the factors influencing their investment decisions.

2) There is no significant difference between investors' investment frequency and the factors influencing their investment decisions.

3) There is no significant difference between investors' sources of fund and the factors influencing their investment decisions.

4) There is no significant difference between investors' investment focus and the factors influencing their investment decisions.

5) There is no significant difference between investors' expected gain and the factors influencing their investment decisions.

The results of the ANOVA tests have been presented in a number of tables (Table 6-10). Table 6 depicts the results of the one way ANOVA test of investors having different level of investment experiences and the factors influencing their stock market investment decisions. Here factors like Company reputation, Accounting Information, and Investors' Action in Specific Situations have significance values of less than .05. Thus the influences of these factors significantly vary based on investors' experience level. However, Reliability of Information and Influence of Others (Peer) have significance values of more than .05, indicating that these factors have similar impact on investors having different investment experiences.

Table 6. One Way ANOVA Test of Investors Having Different Levels of Investment Experience

\begin{tabular}{|c|c|c|c|c|c|c|}
\hline Experience (Investment Duration) & & Sum of Squares & df & Mean Square & $\mathrm{F}$ & Sig. \\
\hline \multirow[t]{3}{*}{ Company Specific Attributes (Reputation) } & Between Groups & .950 & 4 & .237 & 3.355 & .012 \\
\hline & Within Groups & 10.259 & 145 & .071 & & \\
\hline & Total & 11.208 & 149 & & & \\
\hline \multirow[t]{3}{*}{ Accounting Information } & Between Groups & 3.120 & 4 & .780 & 3.063 & .019 \\
\hline & Within Groups & 36.922 & 145 & .255 & & \\
\hline & Total & 40.042 & 149 & & & \\
\hline \multirow[t]{3}{*}{ Reliability of Information } & Between Groups & .722 & 4 & .180 & 1.036 & .391 \\
\hline & Within Groups & 25.249 & 145 & .174 & & \\
\hline & Total & 25.970 & 149 & & & \\
\hline \multirow[t]{3}{*}{ Influence of Others (Peer) } & Between Groups & .812 & 4 & .203 & 1.650 & .165 \\
\hline & Within Groups & 17.839 & 145 & .123 & & \\
\hline & Total & 18.652 & 149 & & & \\
\hline \multirow[t]{3}{*}{ Investors' Action in Specific Situations } & Between Groups & 2.938 & 4 & .734 & 4.247 & .003 \\
\hline & Within Groups & 25.072 & 145 & .173 & & \\
\hline & Total & 28.010 & 149 & & & \\
\hline
\end{tabular}

Table 7 shows that there is no significant difference in factors like Reliability of information, Influence of others, and Investors' action in specific situations among investors having different investment frequencies. Nonetheless, 
there is a significant difference among such investors in the case of factors like Company Reputation and Accounting Information.

Table 7. One Way ANOVA Test of Investors Investing in Different Investment Frequencies

\begin{tabular}{|c|c|c|c|c|c|c|}
\hline \multirow[b]{2}{*}{ Investment Frequency } & & \multirow[b]{2}{*}{ Sum of Squares } & \multicolumn{3}{|c|}{ Mean } & \multirow[b]{2}{*}{ Sig. } \\
\hline & & & df & Square & $\mathrm{F}$ & \\
\hline \multirow[t]{3}{*}{ Company Specific Attributes (Reputation) } & Between Groups & .625 & 3 & .208 & 2.874 & .038 \\
\hline & Within Groups & 10.583 & 146 & .072 & & \\
\hline & Total & 11.208 & 149 & & & \\
\hline \multirow[t]{3}{*}{ Accounting Information } & Between Groups & 2.941 & 3 & .980 & 3.857 & .011 \\
\hline & Within Groups & 37.101 & 146 & .254 & & \\
\hline & Total & 40.042 & 149 & & & \\
\hline \multirow[t]{3}{*}{ Reliability of Information } & Between Groups & .231 & 3 & .077 & .436 & .727 \\
\hline & Within Groups & 25.740 & 146 & .176 & & \\
\hline & Total & 25.970 & 149 & & & \\
\hline \multirow[t]{3}{*}{ Influence of Others (Peer) } & Between Groups & .067 & 3 & .022 & .175 & .913 \\
\hline & Within Groups & 18.585 & 146 & .127 & & \\
\hline & Total & 18.652 & 149 & & & \\
\hline \multirow[t]{3}{*}{ Investors' Action in Specific Situations } & Between Groups & .057 & 3 & .019 & .099 & .961 \\
\hline & Within Groups & 27.953 & 146 & .191 & & \\
\hline & Total & 28.010 & 149 & & & \\
\hline
\end{tabular}

As presented in Table 8, investors having different forms or sources of fund for stock market investment are influenced in similar way by Company reputation, Peer Influence, and also they act similarly in specific situations. Conversely, Accounting information and Reliability of information are the factors that significantly differ in influencing such investors having different fund sources.

Table 8. One Way ANOVA Test of Investors Having Different Sources of Fund

\begin{tabular}{|c|c|c|c|c|c|c|}
\hline Sources of Finance & & Sum of Squares & df & $\begin{array}{l}\text { Mean } \\
\text { Square }\end{array}$ & $\mathrm{F}$ & Sig. \\
\hline \multirow[t]{3}{*}{ Company Specific Attributes (Reputation) } & Between Groups & .447 & 2 & .224 & 3.056 & .050 \\
\hline & Within Groups & 10.761 & 147 & .073 & & \\
\hline & Total & 11.208 & 149 & & & \\
\hline \multirow[t]{3}{*}{ Accounting Information } & Between Groups & 13.620 & 2 & 6.810 & 37.889 & .000 \\
\hline & Within Groups & 26.422 & 147 & .180 & & \\
\hline & Total & 40.042 & 149 & & & \\
\hline \multirow[t]{3}{*}{ Reliability of Information } & Between Groups & 2.040 & 2 & 1.020 & 6.265 & .002 \\
\hline & Within Groups & 23.931 & 147 & .163 & & \\
\hline & Total & 25.970 & 149 & & & \\
\hline \multirow[t]{3}{*}{ Influence of Others (Peer) } & Between Groups & .703 & 2 & .352 & 2.879 & .059 \\
\hline & Within Groups & 17.949 & 147 & .122 & & \\
\hline & Total & 18.652 & 149 & & & \\
\hline \multirow[t]{3}{*}{ Investors' Action in Specific Situations } & Between Groups & .423 & 2 & .212 & 1.127 & .327 \\
\hline & Within Groups & 27.587 & 147 & .188 & & \\
\hline & Total & 28.010 & 149 & & & \\
\hline
\end{tabular}

According to Table 9, investors having diverse investment focuses differ significantly in their reliance on factors like Company attributes, Accounting information, and Reliability of information. On the other hand, such investors identically depend on Others' influence and also act in specific situations irrespective of their differences in investment thoughts. 
Table 9. One Way ANOVA Test of Investors Having Different Investment Focuses

\begin{tabular}{|c|c|c|c|c|c|c|}
\hline Investment Thought & & $\begin{array}{l}\text { Sum of } \\
\text { Squares }\end{array}$ & df & $\begin{array}{l}\text { Mean } \\
\text { Square }\end{array}$ & $\mathrm{F}$ & Sig. \\
\hline \multirow[t]{3}{*}{ Company Specific Attributes (Reputation) } & Between Groups & .890 & 3 & .297 & 4.200 & .007 \\
\hline & Within Groups & 10.318 & 146 & .071 & & \\
\hline & Total & 11.208 & 149 & & & \\
\hline \multirow[t]{3}{*}{ Accounting Information } & Between Groups & 3.954 & 3 & 1.318 & 5.332 & .002 \\
\hline & Within Groups & 36.088 & 146 & .247 & & \\
\hline & Total & 40.042 & 149 & & & \\
\hline \multirow[t]{3}{*}{ Reliability of Information } & Between Groups & 1.855 & 3 & .618 & 3.743 & .013 \\
\hline & Within Groups & 24.116 & 146 & .165 & & \\
\hline & Total & 25.970 & 149 & & & \\
\hline \multirow[t]{3}{*}{ Influence of Others (Peer) } & Between Groups & .374 & 3 & .125 & .996 & .396 \\
\hline & Within Groups & 18.277 & 146 & .125 & & \\
\hline & Total & 18.652 & 149 & & & \\
\hline \multirow[t]{3}{*}{ Investors' Action in Specific Situations } & Between Groups & 1.042 & 3 & .347 & 1.881 & .135 \\
\hline & Within Groups & 26.968 & 146 & .185 & & \\
\hline & Total & 28.010 & 149 & & & \\
\hline
\end{tabular}

Following the results of Table 10, it can be said that Accounting information and Investors' action in specific situations are the controlling factors that differ significantly among investors having diverse gain expectations from their stock investments. Nevertheless, Company Specific Attributes (Reputation), Reliability of Information, and Influence of Others are the factors that have identical impact on investors regardless of their distinctly different return anticipations.

Table 10. One Way ANOVA Test of Investors Having Different Gain Expectations

\begin{tabular}{|c|c|c|c|c|c|c|}
\hline Expected Gain & & $\begin{array}{l}\text { Sum of } \\
\text { Squares }\end{array}$ & $\mathrm{df}$ & Mean Square & $\mathrm{F}$ & Sig. \\
\hline \multirow[t]{3}{*}{ Company Specific Attributes (Reputation) } & Between Groups & .365 & 3 & .122 & 1.640 & .183 \\
\hline & Within Groups & 10.843 & 146 & .074 & & \\
\hline & Total & 11.208 & 149 & & & \\
\hline \multirow[t]{3}{*}{ Accounting Information } & Between Groups & 11.091 & 3 & 3.697 & 18.644 & .000 \\
\hline & Within Groups & 28.951 & 146 & .198 & & \\
\hline & Total & 40.042 & 149 & & & \\
\hline \multirow[t]{3}{*}{ Reliability of Information } & Between Groups & .967 & 3 & .322 & 1.881 & .135 \\
\hline & Within Groups & 25.004 & 146 & .171 & & \\
\hline & Total & 25.970 & 149 & & & \\
\hline \multirow[t]{3}{*}{ Influence of Others (Peer) } & Between Groups & .297 & 3 & .099 & .787 & .503 \\
\hline & Within Groups & 18.355 & 146 & .126 & & \\
\hline & Total & 18.652 & 149 & & & \\
\hline \multirow[t]{3}{*}{ Investors' Action in Specific Situations } & Between Groups & 2.497 & 3 & .832 & 4.763 & .003 \\
\hline & Within Groups & 25.513 & 146 & .175 & & \\
\hline & Total & 28.010 & 149 & & & \\
\hline
\end{tabular}

\section{Findings and Recommendations}

The most important factor influencing retail investors' stock market investment decision is Accounting Information which consists of variables such as company EPS, ROE, dividend paid, expected non-cash dividends, growth and debt-equity ratio. Having a significant portion of investor with extensive investment experience, it is logical to get Accounting Information as the most important factor considered by investors in planning their investment. However, the least preferred factor by the investors is Company Specific Attributes. That is investors are least concerned about Individual Corporation's size, age, reputation, industry status, etc.

The study also tried to reveal the relative importance of each of these influencing factors with respect to a number of general stock market behavior of investors. It is evident here that accounting information, the most prominent 
influencing factor, differs significantly among investors with respect to their general investment behavior. Thus, the relative importance of this factor significantly varies among investors having different investment experiences, financing forms, investment hubs or focuses, investment frequencies and gain expectations.

The second influencing factor is influence of others (peer), which does not differ significantly among investors having different investment behavior. That is, all investors are influenced by this factor irrespective of their divergent experiences, sources of fund, investment thoughts, investment frequencies and gain expectations. Therefore, the market is likely to be affected by rumor.

Reliability of information is the third factor that has impact on investment decisions of retail investors. Investors having different financing forms and focal points of investment do not uniformly depend on information obtained from various sources such as internet, stock indices, brokers, market movement, etc. However, most of the investors depend on their own fund for stock investment. Besides, majority of the investors focus on the security of their investment in terms of their risk-return trade off as well as potential gain from investment.

Investors' action in specific situations differs significantly depending on their differences in experience and expected gain from investment. However, such actions do not markedly vary for their differences in investment frequencies, financing sources and focuses of investment. It is worth reinstating here that most of the investors are experienced in stock market investment. Moreover, maximum investors' expected gain range from $20 \%$ to $50 \%$ of their stock investments.

Company Specific Attributes is the least influencing factor and the relative importance of this factor depends particularly on investors' experience and investment frequency.

The findings of the study may offer important implications to the concerned parties and thus, proposes recommendations:

- For investors: It is evident from the study that different group of investors behave differently under a certain circumstance. However, investors are recommended to educate themselves on the factors discussed and findings yielded in the study, and make informed decisions while trading.

- For corporations: Companies having their stocks listed in the stock market of Bangladesh should concentrate carefully on those manipulating factors in order to satisfy the requirements of their existing investors, and also to draw the attention of prospective investors in their stocks. General investors face problems in understanding financial reporting by corporations (Lee and Tweedie, 1975a; 1975b; 1976). Corporations should address such problems by maintaining proper disclosure and ensuring transparency in their financial statements.

- For regulators: Regulators of stock market of Bangladesh should update their guidelines, policies and strategies keeping this decision making variables of investors in view so that they can maintain coordination between investors' preference and their efforts to stabilize the market. In this regard, they should launch different awareness programs for the actual and potential investors in stock market.

- For investment managers: Investment decisions are generally taken by investors and/or their investment managers on their behalf. Thus, investment companies, stock brokers and dealers should also be aware of the factors so that they can educate the unaware investors based on these issues, and help manage their stock portfolios.

\section{Conclusion}

This study was an endeavor to recognize the factors influencing the buying behavior of investors in the equity market of Bangladesh. The results divulged by the respondents endorse that there are a number of individual variables that are considered important by average equity investors. Those variables as well as the factors comprising of the variables affect the general investment behavior of active investors in Bangladesh. The literature summarized the view that accounting information, peer influence and dependability of information are the top three factors that significantly impact the equity investment decisions here. The study findings expose the basic channel to all the companies listed in the stock market of Bangladesh as well as other concerned parties, and thus, direct them to pay attention to the factors accordingly.

The research emerges with a fairly precise view of the average equity investor in Bangladesh stock market. However, experienced and knowledgeable investors would readily acknowledge the composition and relative weights of the scrutinized factor categories to reflect a very basic and unripe investors' profile. Further study can be attempted including institutional investors along with individuals in order to elaborate the understanding of factors influencing investors' behavior, on the whole, in stock market. 


\section{References}

Akhter, R., \& Ahmed, S. (2013). Behavioral Aspects of Individual Investors for Investment in Bangladesh Stock Market. International Journal of Ethics in Social Sciences, 1(1), 15-26.

Al-Tamimi, H. A. H. (2006). Factors influencing individual investor behavior: an empirical study of the UAE financial markets. The Business Review, 5(2), 225-233.

Aregbeyen, O., \& Mbadiugha, S. O. (2011). Factors Influencing Investors Decisions in Shares of Quoted Companies in Nigeria. The Social Sciences, 6(3), 205-212. http://dx.doi.org/10.3923/sscience.2011.205.212

Barber, B. M., \& Odean, T. (1999). The courage of misguided convictions. Financial Analysts Journal, 55(6), 41-55. http://dx.doi.org/10.2469/faj.v55.n6.2313

Barber, B. M., \& Odean, T. (2008). All that glitters: The effect of attention and news on the buying behavior of individual and institutional investors. Review of Financial Studies, 21(2), 785-818. http://dx.doi.org/10.1093/rfs/hhm079

Barber, B. M., \& Odean, T. (2000). Trading is hazardous to your wealth: The common stock investment performance of individual investors. The Journal of Finance, 55(2), 773-806. http://dx.doi.org/10.1111/0022-1082.00226

Baker, M., \& Wurgler, J. (2007). Investor sentiment in the stock market. The Journal of Economic Perspectives, 21(2), 129-151. http://dx.doi.org/10.1257/jep.21.2.129

Baker, M., Wurgler, J., \& Yuan, Y. (2012). Global, local, and contagious investor sentiment. Journal of Financial Economics, 104(2), 272-287. http://dx.doi.org/10.1016/j.jfineco.2011.11.002

Bennet, E., Selvam, D. M., Ebenezer, E., Karpagam, V., \& Vanitha, S. (2011). Investors' attitude on stock selection decision. International Journal of Management \& Business Studies, 1(2), 7-15.

Bhatt, D. K. (2013). Investment and Trading Pattern of Individuals Dealing in Stock Market. The Standard International Journals Transactions on Industrial, Financial \& Business Management (IFBM), 1(2), 67-74.

Centre for Policy Dialogue. (2011). Annual Report. Dhaka: Centre for Policy Dialogue.

Chong, T. P., \& Lai, M. M. (2011). An empirical evidence of factors in equity selection process in Malaysia. African Journal of Business Management, 5(15), 6221.

Conrad, J., Kapadia, N., \& Xing, Y. (2014). Death and jackpot: Why do individual investors hold overpriced stocks?. Journal of Financial Economics, 113(3), 455-475. http://dx.doi.org/10.1016/j.jfineco.2014.04.001

Elan, S. L. (2010). Behavioral patterns and pitfalls of US investors. In Federal Research Division, Library of Congress.

Faruqui, F., \& Rahman, M. H. (2013). Factors Influencing the Crash in the Share Market in Dhaka Stock Exchange. Research Journal of Finance and Accounting, 4(7), 139-147.

Farzana, W., Rahman, M. I., \& Mazumder, M. N. H. (2012). Behavioral Financing: Demographic Factors and Services of Brokerage Houses in Bangladesh. World Journal of Social Sciences, 2(4), 15-33.

Grinblatt, M., \& Keloharju, M. (2000). The investment behavior and performance of various investor types: a study of Finland's unique data set. Journal of financial economics, 55(1), 43-67. http://dx.doi.org/10.1016/S0304-405X(99)00044-6

Hossain, M. F., \& Nasrin, S. (2012). Factors Affecting Selection of Equity Shares: The Case of Retail Investors in Bangladesh. European Journal of Business and Management, 4(20), 110-124.

Hossain, M. S., \& Uddin, M. G. S. (2011). Efficiency Analysis and Volatility Effect of Bangladesh Stock Market. In Cambridge Business \& Economics Conference.

Iqbal, A., \& Usmani, S. (2009). Factors Influencing Individual Investor Behavior (The Case of the Karachi Stock Exchange). South Asian Journal of Management Sciences, 3(1), 15-26.

Jagongo, A. O., \& Mutswenje, V. S. (2014). A survey of the factors influencing investment decisions: the case of individual investors at the NSE.

Jains, D., \& Dashora, N. (2012). A Study on Impact of Market Movements on Investment Decision" An Empirical Analysis with Respect to Investors in Udaipur, Rajasthan. Researchers World, 3(2 Part 2), 78.

Jannatunnesa. (2015). Behavioral Outline of Individual Investors in Stock Market: A Study on Dhaka Stock Exchange. Contemporary Issues in Business and Research, 1(December), 155-81. Dhaka: Department of 
Business Administration, East West University. ISBN -978-984-33-9383-8

Jariwala, H. V. (2015). Analysis of Financial Literacy Level of Retail Individual Investors of Gujarat State and Its Effect on Investment Decision. Journal of Business \& Finance Librarianship, 20(1-2), 133-158. http://dx.doi.org/10.1080/08963568.2015.977727

Joshi, D. J., Khushboo, A., \& Desai, R. (2011). Factors Affecting Equity Investors' Behavior. Chief patron chief patron.

Kahneman, D., \& Tversky, A. (1979). Prospect theory: An analysis of decision under risk. Econometrica: Journal of the Econometric Society, 263-291. http://dx.doi.org/10.2307/1914185

Kaleem, A., Wajid, R. A., \& Hussain, H. S. (2009). Factors Affecting Financial Advisor's Perception in Portfolio Management: With Reference to Pakistan. In 2009 Oxford Business and Economics Conference Program, June 24 (Vol. 26).

Kamesaka, A., Nofsinger, J.R. \& Kawakita, H. (2003). Investment patterns and performance of investor groups in Japan. Pacific-Basin Finance Journal, 11(1), 1-22. http://dx.doi.org/10.1016/S0927-538X(02)00095-1

Kamstra, M. J., Kramer, L. A., \& Levi, M. D. (2003). Winter blues: A SAD stock market cycle. The American Economic Review, 93(1), 324-343. http://dx.doi.org/10.1257/000282803321455322

Kumar, A. (2009). Hard-to-value stocks, behavioral biases, and informed trading. Journal of Financial and Quantitative Analysis, 44(06), 1375-1401. http://dx.doi.org/10.1017/S0022109009990342

Lee, T. A., \& Tweedie, D. P. (1975a). Accounting Information: An Investigation of Private Shareholder Usage, Accounting \& Business Research, 5 (20), 280-291. http://dx.doi.org/10.1080/00014788.1975.9728653

Lee, T. A., \& Tweedie, D. P. (1975b). Accounting Information: An Investigation of Private Shareholder $\begin{array}{llllll}\text { Understanding, Accounting } \quad \& \quad \text { Business } & \text { Research, } & 6 & \text { (21), } & \text { 3-17. }\end{array}$ http://dx.doi.org/10.1080/00014788.1975.9728662

Lee, T. A., \& Tweedie, D. P. (1976). The private shareholder-his sources of information and his understanding of reporting practices, Accounting \& Business Research, 6(24), 304-314. http://dx.doi.org/10.1080/00014788.1976.9728696

Lodhi, S. (2014). Factors influencing individual investor behavior: An empirical study of city Karachi. Journal of Business and Management, 16(2), 68-76.

Mobarek, A., Mollah, S., \& Keasey, K. (2014). A cross-country analysis of herd behavior in Europe. Journal of International Financial Markets, Institutions and Money, 32, 107-127. http://dx.doi.org/10.1016/j.intfin.2014.05.008

Mohacsy, I., \& Lefer, H. (2007). Money and sentiment: a psychodynamic approach to behavioral finance. Psychodynamic Psychiatry, 35(3), 455. http://dx.doi.org/10.1521/jaap.2007.35.3.455

Mohanta, G., \& Debasish, S. S. (2011). A study on investment preferences among urban investors in Orissa. Prerna Journal of Management Thought and Practice, 1-9.

Merikas, A. A., Merikas, A. G., Vozikis, G. S., \& Prasad, D. (2011). Economic factors and individual investor behavior: The case of the Greek stock exchange. Journal of Applied Business Research, 20(4). http://dx.doi.org/10.19030/jabr.v20i4.2227

Mills, K., Steven, M., \& Warren, T. (1995). The influence of financial factors on corporate investment. Australian Economic Review, 28(2), 50-64. http://dx.doi.org/10.1111/j.1467-8462.1995.tb00889.x

Nagy, R. A., \& Obenberger, R. W. (1994). Factors influencing individual investor behavior. Financial Analysts Journal, 50(4), 63-68. http://dx.doi.org/10.2469/faj.v50.n4.63

Odean, T. (1998a). Are investors reluctant to realize their losses? The Journal of finance, 53(5), 1775-1798. http://dx.doi.org/10.1111/0022-1082.00072

Odean, T. (1998b). Do investors trade too much?. Available at SSRN 94143.

Prosad, J. M. (2014). Impact of Investors' Behavioral Biases on the Indian Equity Market and Implications on Stock Selection Decisions: An Empirical Analysis (Doctoral dissertation, Jaypee Institute of Information Technology).

Rakesh, H. M. (2014). A study on individuals investors behavior in stock markets of India. International Journal in Management \& Social Science, 2(2), 165-174. 
Rashid, M., \& Nishat, M. A. (2009). Satisfaction of retail investors on the structural efficiency of the market: evidence from a developing country context. Asian Academy of Management Journal, 14(2), 41-64.

Sehgal, S., \& Tripathi, V. (2007). Value effect in Indian stock market. The ICFAI Journal of Applied Finance, 13(1), 23-36.

Sewell, M. (2010). Behavioral Finance, University of Cambridge. working paper.

Shefrin, H., \& Statman, M. (1985). The disposition to sell winners too early and ride losers too long: Theory and evidence. The Journal of finance, 40(3), 777-790. http://dx.doi.org/10.1111/j.1540-6261.1985.tb05002.x

Shiller, R. J. (2000). Measuring bubble expectations and investor confidence. The Journal of Psychology and Financial Markets, 1(1), 49-60. http://dx.doi.org/10.1207/S15327760JPFM0101_05

Shumway, T., \& Wu, G. (2006). Does Disposition Drive Momentum? University of Michigan. working paper.

Stambaugh, R. F., Yu, J., \& Yuan, Y. (2012). The short of it: Investor sentiment and anomalies. Journal of Financial Economics, 104(2), 288-302. http://dx.doi.org/10.1016/j.jfineco.2011.12.001

Statman, M. (2008). What is Behavioral Finance? Handbook of Finance, 2. New Jersey: John Wiley \& Sons, Inc.

Viswanadham, N., Edward, N., \& Mwakapala, D. (2014). A Study of Perceptual Factors Influencing Investors buying Behavior in Tanzanian Equity Market. Journal of Finance and Investment Analysis, 3(2).

Yu, J., \& Yuan, Y. (2011). Investor sentiment and the mean-variance relation. Journal of Financial Economics, 100(2), 367-381. http://dx.doi.org/10.1016/j.jfineco.2010.10.011

\section{Note}

Note 1. 1 US Dollar = Bangladeshi Taka $(B D T) 79.95$ (as of January 13, 2017 as in Universal Currency Converter)

\section{Copyrights}

Copyright for this article is retained by the author(s), with first publication rights granted to the journal.

This is an open-access article distributed under the terms and conditions of the Creative Commons Attribution license (http://creativecommons.org/licenses/by/4.0/). 